\title{
Effects of Cortisol and Salinity Challenge on Water Balance in Developing Larvae of Tilapia (Oreochromis mossambicus)
}

\author{
Li-Yih $\operatorname{Lin}^{1}$ \\ Ching-Feng Weng ${ }^{2}$ \\ Pung-Pung Hwang ${ }^{1,2, *}$ \\ ${ }^{1}$ Institute of Fisheries Science, National Taiwan University, \\ Taipei, Taiwan, Republic of China; ${ }^{2}$ Institute of Zoology, \\ Academia Sinica, Nankang, Taipei, Taiwan, Republic of \\ China
}

Accepted 2/22/00

\begin{abstract}
Effects of exogenous cortisol on drinking rate and water content in developing larvae of tilapia (Oreochromis mossambicus) were examined. Both freshwater- and seawater-adapted larvae showed increases in drinking rates with development. Drinking rates of seawater-adapted larvae were about four- to ninefold higher than those of freshwater-adapted larvae from day 2 to day 5 after hatching. Seawater-adapted larvae showed declines in drinking rate and water content at 4 and $14 \mathrm{~h}$, respectively, after immersion in $10 \mathrm{mg} \mathrm{L}^{-1}$ cortisol. In the case of freshwateradapted larvae, the drinking rate decreased after $8 \mathrm{~h}$ of cortisol immersion, while the water content did not show a significant change even after $32 \mathrm{~h}$ of cortisol immersion. In a subsequent experiment of transfer from freshwater to $20 \mathrm{ppt}$ (parts per thousand, salinity) seawater, immersion in $10 \mathrm{mg} \mathrm{L}^{-1}$ cortisol for $8-24 \mathrm{~h}$ enhanced the drinking rate in larvae at $4 \mathrm{~h}$ after transfer, but no significant difference was found in water contents between cortisol-treated and control groups following transfer. These results suggest that cortisol is involved in the regulation of drinking activity in developing tilapia larvae.
\end{abstract}

\section{Introduction}

Marine fish living in hypertonic environments have the ability to balance osmotic water loss by drinking seawater and to excrete excess ions by means of mitochondria-rich (MR) cells on the gill filaments (Eddy 1982). Several hormones have been ${ }^{*}$ To whom correspondence should be addressed; e-mail: zophwang@
ccvax.sinica.edu.tw.

Physiological and Biochemical Zoology 73(3):283-289. 2000. (C) 2000 by The University of Chicago. All rights reserved. 1522-2152/2000/7303-9964\$03.00 suggested to control the regulating mechanisms for water balance (Hazon and Balment 1998). In teleosts, cortisol is one of the major corticosteroids and has both glucocorticoid and mineralocorticoid functions. Cortisol is thought to be a seawateradapting hormone because it promotes salt excretion in hypoosmoregulating fish (Pickford et al. 1970; Richman et al. 1987; Madsen 1990). Previous studies indicated that this function might be achieved through stimulation of gill $\mathrm{Na}^{+}-\mathrm{K}^{+}$ATPase activity and development of branchial MR cells (Madsen 1990; McCormick 1990; Ayson et al. 1995). Recently, exogenous cortisol was shown to stimulate drinking in salmon presmolt and rainbow trout juveniles, suggesting that cortisol is also involved in the regulation of another hypoosmoregulatory mechanism, water drinking (Fuentes et al. 1996).

Embryos and larvae of several teleosts whose gills or kidneys are poorly or underdeveloped have been found to be capable of maintaining constancy in ion concentrations and osmolality of their body fluids as well as adults do (Alderdics 1988). Recent studies have demonstrated the ion-regulation abilities of embryos and larvae, i.e., the active secretion of $\mathrm{NaCl}$ in seawater (SW) and absorption of $\mathrm{Ca}^{2+}$ in freshwater (FW) via skin MR cells (Guggino 1980a; Hwang and Hirano 1985; Hwang 1990; Hwang et al. 1994, 1999). Moreover, mechanisms of water balance, which are conducted through drinking activities, were also found to be developed in early developmental stages of teleosts, including embryos of killifish (Guggino 1980b), larvae of cod (Mangor-Jensen and Adoff 1987), halibut (Tytler and Blaxter 1988), rainbow trout (Tytler et al. 1990), and tilapia (Miyazaki et al. 1998). However, little is known about the hormonal control for these mechanisms of ion and water balance in early developmental stages of fish.

Previous studies have demonstrated the presence of cortisol in embryos and larvae whose internal glands have not yet developed (De Jesus et al. 1991; Hwang et al. 1992). Moreover, cortisol was suggested to play a positive role in hypoosmoregulation of larvae by enhancing the regulation of body osmolality and $\mathrm{Na}^{+}$content upon SW challenges (Hwang and Wu 1993; Lin et al. 1999) and to stimulate the development of yolk-sac MR cells (Ayson et al. 1995). However, the acting mechanism of cortisol in larval hypoosmoregulation is unclear. Since activation of water uptake is also critical for larval hypoosmoregulation, we hypothesize that cortisol is also involved in the regulation of water balance in developing larvae. In the developing larvae of some euryhaline teleosts, hypoosmoregulation mechanisms were stimulated within several hours after transfer from FW to SW (Hwang and Hirano 1985; Hwang 
1990; Lin et al. 1999). Moreover, some studies suggested shortterm (several hours to 1 or $2 \mathrm{~d}$ ) actions of cortisol on hypoosmoregulation in teleosts upon SW challenges (Forrest et al. 1973; McCormick 1995; Lin et al. 1999; Marshall et al. 1999). Therefore, in this study, short-term effects of exogenous cortisol on water content and drinking rate in tilapia larvae adapted to FW or SW, or transferred directly from FW to SW, were examined.

\section{Material and Methods}

\section{Fish}

Mature tilapia (Oreochromis mossambicus) from the Tainan branch of the Fisheries Research Institute were reared in circulating $\mathrm{FW}$ at $26^{\circ}-28^{\circ} \mathrm{C}$ under a photoperiod of $12 \mathrm{~L}: 12 \mathrm{D}$.

Fertilized eggs were retrieved from the mouth of females about $24 \mathrm{~h}$ before hatching. Embryos were incubated in aerated FW at the same conditions as adults. Part of the brood was adapted to $20 \mathrm{ppt}$ (parts per thousand, salinity) SW for $1 \mathrm{~d}$ and then transferred to $32 \mathrm{ppt} \mathrm{SW}$ as SW larvae. During this transfer process, the embryos adapted well to $32 \mathrm{ppt}$ SW with a mortality of $<5 \%$. The incubation water was changed daily to control water quality. All experiments were conducted on yolk-sac larvae, and no feeding occurred.

\section{Measurement of Drinking Rate}

Drinking rate of larvae was measured by using isotope-labeled dextran as a tracer following previous studies (Guggino 1980b; Mangor-Jensen and Adoff 1987; Tytler and Blaxter 1988).

The initial stock solutions of ${ }^{14} \mathrm{C}$-dextran (SA $0.75 \mathrm{mCi}$ $\mathrm{mM}^{-1}$, Du Pont) were made by dissolving $250 \mu \mathrm{Ci}$ tracer in 4 $\mathrm{mL}$ double-deionized water, and then $1 \mathrm{~mL}$ of stock solution was added into $25 \mathrm{~mL}$ of aquarium water to give an exposure medium with an approximate activity of $2.5 \mu \mathrm{Ci} \mathrm{mL} \mathrm{m}^{-1}$. The larvae were incubated in the exposure medium at $27^{\circ} \mathrm{C}$ for 1 h. After exposure, the larvae were transferred with a widemouthed dropper to an isotope-free water bath for $3 \mathrm{~min}$ to remove most adhering tracer on the integument. Preliminary experiments, in which gut and the rest of the larval body were separated for radioactivity measurement, confirmed that the radioactivity of adhering tracer on the integument was only about 1.5- to twofold that of the background and could be neglected. Therefore, whole larva was rinsed, anesthetized on ice, and digested with tissue solubilizer (Soluene-350, Packard, Meriden, Conn.) in a counting vial at $50^{\circ} \mathrm{C}$ for $4 \mathrm{~h}$. After solubilization, counting solution (Hionic-Fluor, Packard, Meriden, Conn.) was added to each vial. The radioactivities of both the incubation medium and the solubilized larvae were measured by liquid scintillation counter (LS 6500, Beckman, Fullerton, Calif.). The plot of radioactivity against time was linear within the first hour in both FW and SW larvae; therefore, 1 $\mathrm{h}$ of exposure time was chosen to determine the drinking rate in the following experiments. Drinking rate was calculated by the equation:

$$
\text { Drinking rate }=(R-C) /(M \times T) \text {, }
$$

where $R$ is the total radioactivity of the sample after accumulation of tracer for $1 \mathrm{~h}\left(\mathrm{dpm}\right.$ larva $\left.^{-1}\right), C$ is the background radioactivity obtained from the larva without exposure to tracer, $M$ is the specific radioactivity of the exposure medium $\left(\mathrm{dpm} \mathrm{nL} \mathrm{L}^{-1}\right)$, and $T$ is the time of exposure (h). Drinking rate was expressed as $\mathrm{nL}$ larva ${ }^{-1} \mathrm{~h}^{-1}$ in order to compare with the data of previous studies.

\section{Measurement of Water Content and Body Size}

Sampled larvae were rinsed with double-deionized water and then wiped off with filter paper. The dry weight of each larva was measured after drying in a $60^{\circ} \mathrm{C}$ oven until the weight was constant. Water content was calculated as wet weight minus dry weight. The total length and yolk-sac diameter were measured under a dissecting microscope equipped with a micrometer on the eyepiece.

Experiment 1: Effects of Various Doses of Cortisol on Water Balance in SW Larvae

Cortisol (hydrocortisone, 21-hemisuccinate, Sigma, St. Louis, Mo.) was dissolved in double-deionized water and then diluted with SW or FW to give different concentrations $(0.1,1,5$, and $10 \mathrm{mg} \mathrm{L}^{-1}$ ) of immersing solutions. Preliminary experiments confirmed that immersion of $10 \mathrm{mg} \mathrm{L}^{-1}$ cortisol for $4-8 \mathrm{~h}$ resulted in about 10 -fold increases in whole-body cortisol content of larvae (data not shown), similar to our previous study (Lin et al. 1999).

The experiment was designed to determine whether the effects of cortisol on larval water balance are dose related. Fourday-old SW larvae were immersed in cortisol solution for 24 $\mathrm{h}$ and then were sampled for measurements of body size, water content, and drinking rate.

Experiment 2: Effects of Various Times of Cortisol Immersion on Water Balance in SW and FW Larvae

This experiment was aimed to examine the time-course changes in various parameters of water balance in larvae treated with cortisol. SW and FW larvae were immersed in $10 \mathrm{mg} \mathrm{L}^{-1}$ cortisol solutions for various times: $2,4,8,14$, or $24 \mathrm{~h}$ for SW larvae and 8,16 , or $32 \mathrm{~h}$ for FW larvae, respectively. Then the larvae were sampled for measurements similar to those in experiment 1 . 
Table 1: Changes in drinking rate of freshwater and seawater larvae with development

\begin{tabular}{|c|c|c|c|c|}
\hline \multirow{2}{*}{$\begin{array}{l}\text { Days } \\
\text { after } \\
\text { Hatching }\end{array}$} & \multicolumn{2}{|l|}{ FW Larvae } & \multicolumn{2}{|l|}{ SW Larvae } \\
\hline & $\mathrm{nL} \mathrm{h}^{-1} \mathrm{mg}^{-1}$ & $\mathrm{~nL} \mathrm{~h}^{-1} \operatorname{larva}^{-1}$ & $\mathrm{~nL} \mathrm{~h}^{-1} \mathrm{mg}^{-1}$ & $\mathrm{~nL} \mathrm{~h}^{-1} \operatorname{larva}^{-1}$ \\
\hline $2 \ldots \ldots \ldots$ & $1.7 \pm .3$ & $9.1 \pm 1.7$ & $7.4 \pm .6$ & $41.4 \pm 3.4$ \\
\hline $5 \ldots \ldots \ldots$ & $7.1 \pm 1.6$ & $52.5 \pm 11.8$ & $60.8 \pm 15.2$ & $468.2 \pm 117.0$ \\
\hline
\end{tabular}

Note. Values represent $\bar{X} \pm \mathrm{SD}(n=10)$.

Experiment 3: Effects of Cortisol Immersion on Water Balance in Larvae Transferred from $F W$ to $S W$

Based on the results of experiments 1 and 2, we hypothesized that cortisol alone might not be able to stimulate larval water drinking and considered that SW might be one of the necessary factors. FW larvae were immersed in $10 \mathrm{mg} \mathrm{L}^{-1}$ cortisol solution (in FW) for $8 \mathrm{~h}$ and then were directly transferred to $20 \mathrm{ppt}$ SW (also containing $10 \mathrm{mg} \mathrm{L}^{-1}$ cortisol). The larvae were sampled for measurements similar to those in experiment 1 at 2, $4,8,16$, or $24 \mathrm{~h}$ after transfer. Ten larvae were sampled for each test condition and for each sampling time in all the experiments.

\section{Results}

\section{Drinking Rates of FW and SW Larvae}

Drinking rates of FW and SW tilapia (Oreochromis mossambicus) larvae were measured on days 2 and 5 after hatching. Table 1 reveals dramatic differences in drinking rates between SW and FW larvae. Both FW and SW larvae showed increases in drinking rates with development. Drinking rates of SW larvae were about fourfold higher than those of FW larvae on day 2 after hatching, and this difference reached nearly ninefold on day 5 after hatching.

Water Balance in SW Larvae after 24 h of Cortisol Immersion

SW larvae treated with cortisol showed significant decreases in drinking rates at concentrations of 5 and $10 \mathrm{mg} \mathrm{L}^{-1}$ (Fig. 1). At concentrations of 5 and $10 \mathrm{mg} \mathrm{L}^{-1}$, larvae also showed significant decreases in wet weight and water content (Table 2 ). The wet weight and water content of $10 \mathrm{mg} \mathrm{L}^{-1}$ cortisolimmersed larvae were about 5.8\% and 9.2\%, respectively, lower than those of control larvae (Table 2). The scale of the decrease in wet weight was equal to that of water content, indicating that the decreased proportion of wet weight was due to water loss. However, cortisol did not affect the other parameters, including dry weight, total length, and yolk-sac diameter of larvae.
Water Balance in SW and FW Larvae Treated with Cortisol for Various Times

Table 3 shows the effects of $10 \mathrm{mg} \mathrm{L}^{-1}$ cortisol on wet weight, water content, dry weight, and drinking rate of 4-d-old SW larvae after various times of cortisol immersion. The drinking rate of larvae decreased significantly after $4 \mathrm{~h}$ of cortisol immersion; however, significant decreases in water content and wet weight did not occur until $14 \mathrm{~h}$ of cortisol immersion (Table 3).

Significant decreases in drinking rates were also found in 4d-old FW larvae after $8 \mathrm{~h}$ of cortisol immersion (Table 4). However, there were still no significant differences between control and cortisol-immersed groups in wet weight and water content even after $32 \mathrm{~h}$ of cortisol immersion (Table 4).

Effects of Cortisol Immersion on Water Balance in Larvae Transferred from $\mathrm{FW}$ to $\mathrm{SW}$

Exogenous cortisol enhanced the drinking rate in larvae upon their transfer from FW to $20 \mathrm{ppt}$ SW. Before transfer to SW

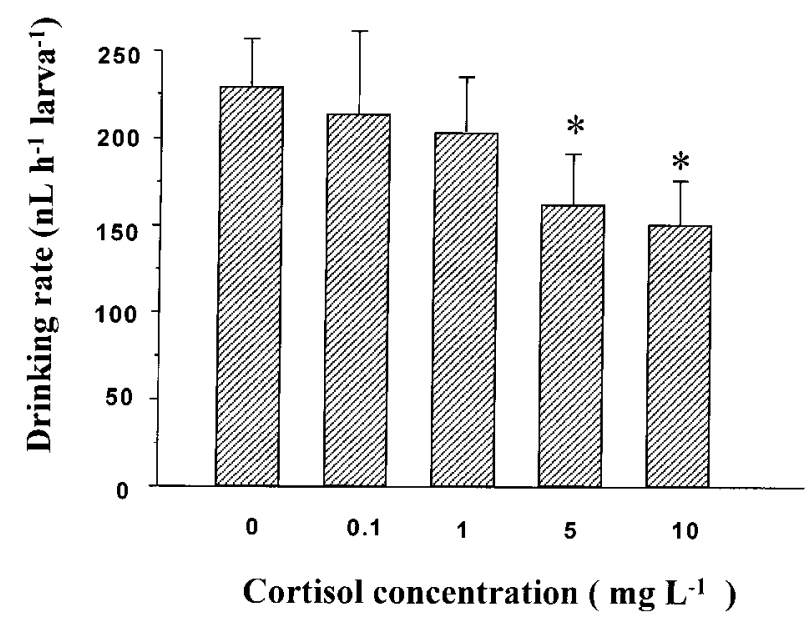

Figure 1. Changes in drinking rate of 4-d-old seawater larvae immersed in different concentrations of cortisol for $24 \mathrm{~h}$. Student's $t$-test analysis was used to assess differences between control and cortisol-immersed groups for each parameter. Values represent $\bar{X} \pm \mathrm{SD}(n=10)$. An asterisk indicates a significant difference from the control value at $P<$ 0.05 . 
Table 2: Changes in body size and water content of 4-d-old seawater larvae immersed in 5 or $10 \mathrm{mg} \mathrm{L}^{-1}$ cortisol for $24 \mathrm{~h}$

\begin{tabular}{|c|c|c|c|c|c|}
\hline $\begin{array}{l}\text { Cortisol } \\
\text { Concentration }\end{array}$ & $\begin{array}{l}\text { Wet } \\
\text { Weight } \\
(\mathrm{mg})\end{array}$ & $\begin{array}{l}\text { Water } \\
\text { Content } \\
(\mathrm{mg})\end{array}$ & $\begin{array}{l}\text { Dry } \\
\text { Weight } \\
(\mathrm{mg})\end{array}$ & $\begin{array}{l}\text { Total } \\
\text { Length } \\
(\mathrm{mm})\end{array}$ & $\begin{array}{l}\text { Yolk-Sac } \\
\text { Diameter } \\
(\mathrm{mm})\end{array}$ \\
\hline 0 & $9.01 \pm .18$ & $650+34$ & $2.51 \pm .21$ & $9.12 \pm .41$ & $1.72 \pm .17$ \\
\hline 5 & $8.43 \pm .22^{*}$ & $6.02 \pm .18^{\star}$ & $2.41 \pm .24$ & $\mathrm{ND}$ & ND \\
\hline $10 \ldots \ldots \ldots \ldots$ & $8.49 \pm .38^{*}$ & $5.90 \pm .21^{*}$ & $2.59 \pm .26$ & $9.07 \pm .21$ & $1.73 \pm .21$ \\
\hline
\end{tabular}

Note. All data were obtained from one brood of tilapia larvae. $\bar{X} \pm \operatorname{SD}(n=10)$ are indicated. Student's $t$ test analysis was used to assess differences between control and cortisol-immersed groups for each parameter. $\mathrm{ND}=$ data not determined. An asterisk indicates that means are significantly different from the control $(P<$ $0.05)$.

(at $0 \mathrm{~h}$ ), the cortisol-treated group showed a lower drinking rate than the control. Both control and cortisol-treated groups increased their drinking rates right after transfer, but the rate of the cortisol-treated group turned out to be significantly higher than that of the control at $4 \mathrm{~h}$ after transfer to SW (Fig. 2 ). Drinking rates of both control and cortisol-treated groups reached the level of SW-adapted group $8 \mathrm{~h}$ after transfer (Fig. 2 ). However, water contents of transferred larvae of both control and cortisol-treated groups were lower than those of SWand FW-adapted groups at 4 and $8 \mathrm{~h}$ after transfer and returned to levels of SW- and FW-adapted groups after $16 \mathrm{~h}$ (Fig. 3). Moreover, no significant difference was found in water contents between the control and cortisol-treated groups of transferred larvae during transfer (Fig. 3).

\section{Discussion}

This study found that exogenous cortisol affects water balance in tilapia (Oreochromis mossambicus) larvae adapted to either SW or FW and promotes larval water drinking upon transfer from FW to SW. These results suggest that cortisol may be involved in the mechanisms of water balance in the early developmental stages of teleosts.

Drinking activity is well developed in early stages of teleosts

Table 3: Changes in body size, water content, and drinking rate of 4-d-old seawater larvae immersed in $10 \mathrm{mg} \mathrm{L}^{-1}$ cortisol for various times

\begin{tabular}{|c|c|c|c|c|}
\hline $\begin{array}{l}\text { Immersion } \\
\text { Time } \\
\text { (h) }\end{array}$ & $\begin{array}{l}\text { Wet } \\
\text { Weight } \\
(\mathrm{mg})\end{array}$ & $\begin{array}{l}\text { Water } \\
\text { Content } \\
(\mathrm{mg})\end{array}$ & $\begin{array}{l}\text { Dry } \\
\text { Weight } \\
(\mathrm{mg})\end{array}$ & $\begin{array}{l}\text { Drinking } \\
\text { Rate } \\
\left(\mathrm{nL} \mathrm{h}^{-1} \text { larva }^{-1}\right)\end{array}$ \\
\hline \multicolumn{5}{|l|}{ 2: } \\
\hline Control ...... & $7.58 \pm .23$ & $4.99 \pm .14$ & $2.59 \pm .11$ & $215.3 \pm 31.5$ \\
\hline Cortisol ...... & $7.67 \pm .22$ & $5.05 \pm .14$ & $2.62 \pm .09$ & $189.1 \pm 37.3$ \\
\hline \multicolumn{5}{|l|}{ 4: } \\
\hline Control ...... & $7.61 \pm .28$ & $5.21 \pm .18$ & $2.40 \pm .18$ & $227.3 \pm 28.6$ \\
\hline Cortisol ...... & $7.75 \pm .21$ & $5.19 \pm .19$ & $2.56 \pm .10$ & $194.5 \pm 24.2^{*}$ \\
\hline \multicolumn{5}{|l|}{ 8: = - = - } \\
\hline Control ....... & $7.91 \pm .21$ & $5.30 \pm .13$ & $2.61 \pm .13$ & $198.1 \pm 28.6$ \\
\hline Cortisol ....... & $7.91 \pm .23$ & $5.29 \pm .12$ & $2.62 \pm .13$ & $145.7 \pm 22.3^{*}$ \\
\hline \multicolumn{5}{|l|}{$14:$} \\
\hline Control ...... & $8.25 \pm .34$ & $5.62 \pm .22$ & $2.63 \pm .16$ & $218.3 \pm 26.4$ \\
\hline Cortisol ....... & $7.88 \pm .39^{*}$ & $5.33 \pm .27^{*}$ & $2.55 \pm .16$ & $188.1 \pm 20.2^{*}$ \\
\hline \multicolumn{5}{|l|}{$24:$} \\
\hline Control ....... & $8.32 \pm .26$ & $5.88 \pm .28$ & $2.44 \pm .16$ & $274.2 \pm 16.2$ \\
\hline Cortisol ....... & $8.05 \pm .21^{\star}$ & $5.62 \pm .19^{*}$ & $2.43 \pm .08$ & $214.5 \pm 43.1^{\star}$ \\
\hline
\end{tabular}

Note. All data were obtained from one brood of tilapia larvae. $\bar{X} \pm \mathrm{SD}(n=10)$ are indicated. Student's $t$-test analysis was used to assess differences between control and cortisol-immersed groups for each parameter. An asterisk indicates that means are significantly different from the control $(P<0.05)$. 
Table 4: Changes in body size, water content, and drinking rate of 4-d-old freshwater larvae immersed in $10 \mathrm{mg} \mathrm{L}^{-1}$ cortisol for various times

\begin{tabular}{|c|c|c|c|c|}
\hline $\begin{array}{l}\text { Immersion } \\
\text { Time } \\
\text { (h) }\end{array}$ & $\begin{array}{l}\text { Wet } \\
\text { Weight } \\
(\mathrm{mg})\end{array}$ & $\begin{array}{l}\text { Water } \\
\text { Content } \\
(\mathrm{mg})\end{array}$ & $\begin{array}{l}\text { Dry } \\
\text { Weight } \\
(\mathrm{mg})\end{array}$ & $\begin{array}{l}\text { Drinking } \\
\text { Rate } \\
\left(\mathrm{nL} \mathrm{h}^{-1} \text { larva }^{-1}\right)\end{array}$ \\
\hline \multicolumn{5}{|l|}{ 8: } \\
\hline Control ...... & $6.96 \pm .42$ & $4.81 \pm .30$ & $2.15 \pm .17$ & $86.4 \pm 12.5$ \\
\hline Cortisol ...... & $7.21 \pm .26$ & $5.04 \pm .16$ & $2.17 \pm .13$ & $43.6 \pm 12.1^{*}$ \\
\hline \multicolumn{5}{|l|}{$16:$} \\
\hline Control ...... & $7.16 \pm .37$ & $5.06 \pm .28$ & $2.10 \pm .14$ & $109.3 \pm 20.3$ \\
\hline Cortisol ....... & $7.27 \pm .27$ & $5.13 \pm .19$ & $2.14 \pm .12$ & $45.7 \pm 10.5^{*}$ \\
\hline \multicolumn{5}{|l|}{$32:$} \\
\hline Control ...... & $7.66 \pm .41$ & $5.63 \pm .35$ & $2.03 \pm .21$ & $156.3 \pm 33.1$ \\
\hline Cortisol ....... & $7.69 \pm .18$ & $5.65 \pm .21$ & $2.04 \pm .13$ & $128.4 \pm 25.6^{\star}$ \\
\hline
\end{tabular}

Note. All data were obtained from one brood of tilapia larvae. $\bar{X} \pm \operatorname{SD}(n=10)$ are indicated. Student's $t$-test analysis was used to assess differences between control and cortisol-immersed groups for each parameter. An asterisk indicates that means are significantly different from the control $(P<0.05)$.

as described above (Guggino 1980b; Mangor-Jensen and Adoff 1987; Tytler and Blaxter 1988; Tytler et al. 1990; Miyazaki et al. 1998). During acute salinity challenges, tilapia larvae show profound changes in drinking rate, i.e., increased or decreased drinking rate within several hours while facing hypertonic or hypotonic challenges, to maintain constancy of their body fluids for normal development and survival (L.-Y. Lin, C.-F. Weng, and P.-P. Hwang, unpublished data). It is interesting and important to determine whether hormones regulate this rapid regulation in water balance upon salinity challenges. In this

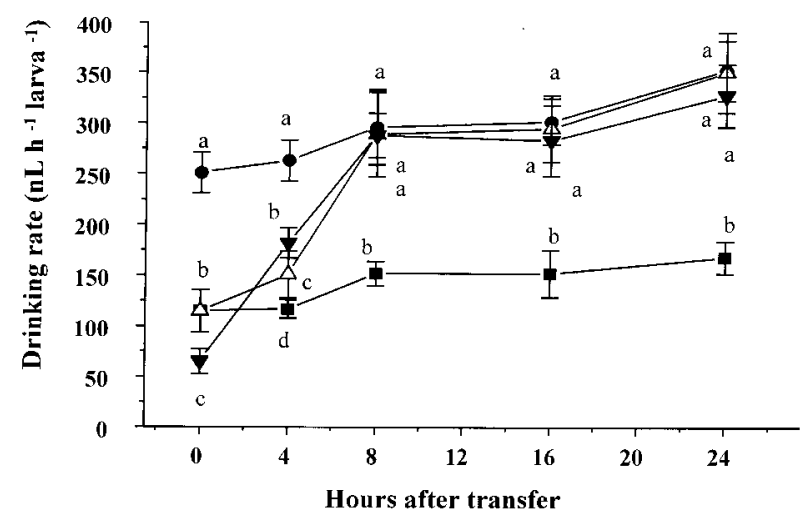

Figure 2. Changes in drinking rate of cortisol-treated freshwater (FW) larvae (solid triangles) and sham FW larvae (open triangles) after transfer to $20 \mathrm{ppt}$ seawater (SW). Drinking rates of FW larvae (squares) and SW larvae (circles), which were kept in FW and SW, respectively, are also shown. Treatment of cortisol refers to experiment 3 of "Material and Methods." One-way ANOVA (Tukey's pairwise comparisons) analysis was used to assess differences among different groups at the same time. Values represent $\bar{X} \pm \mathrm{SD}(n=10)$. Different letters indicate a significant difference $(P<0.05)$. study, exogenous cortisol promotes drinking activity in larvae transferred from FW to SW. This finding supports our hypothesis that cortisol can promote hypoosmoregulation of larvae by upregulating drinking. FW-adapted salmon (Salmo salar) and rainbow trout (Oncorhynchus mykiss) juveniles implanted with $80 \mathrm{mg} \mathrm{kg}^{-1}$ cortisol for 3 wk showed no significant changes in drinking but developed a greater drinking rate than did sham fish following transfer to SW (Fuentes et al. 1996). Administration of cortisol at $150 \mathrm{mg} \mathrm{kg} \mathrm{m}^{-1}$ in the diet for 8-12 $\mathrm{d}$ or immersion of cortisol at $10 \mathrm{mg} \mathrm{L}^{-1}$ for $1-5 \mathrm{~d}$ could increase the survival of tilapia larvae after transfer from FW to SW by diminishing the degree of increase in larval body osmolality or $\mathrm{Na}^{+}$content (Hwang and Wu 1993; Lin et al. 1999). In the paper by Ayson et al. (1995), immersion in 0.1-100 mg L $\mathrm{m}^{-1}$ cortisol for 3-9 d stimulated the size and number of yolk-sac MR cells in FW tilapia larvae. Taken together, involvement of cortisol in the hypoosmoregulation of larvae acclimating to SW may include enhancement of water drinking and stimulation of ion regulation and development of MR cells.

For most previous studies, it generally took several days to weeks for the treatments of exogenous cortisol to induce stimulation of hypoosmoregulation (see review by McCormick 1995). Only a very few studies have so far discussed short-term (several hours to 1 or $2 \mathrm{~d}$ ) actions of cortisol in teleosts (Forrest et al. 1973; Lin et al. 1999; this study). In a recent study on killifish (Fundulus heteroclitus), Marshall et al. (1999) argued that the dramatic change in cortisol level within 1-8 h after transfer from FW to SW is a major cue for target tissues to switch the expression of seawater-adaptive proteins, based on the time-course changes in blood cortisol and $\mathrm{Na}^{+}$(Marshall et al. 1999), as well as the expression of gill kfCFTR (a homologue of cystic fibrosis transmembrane conductance regulator) that is associated with the $\mathrm{Cl}^{-}$secretion in gills (Singer 


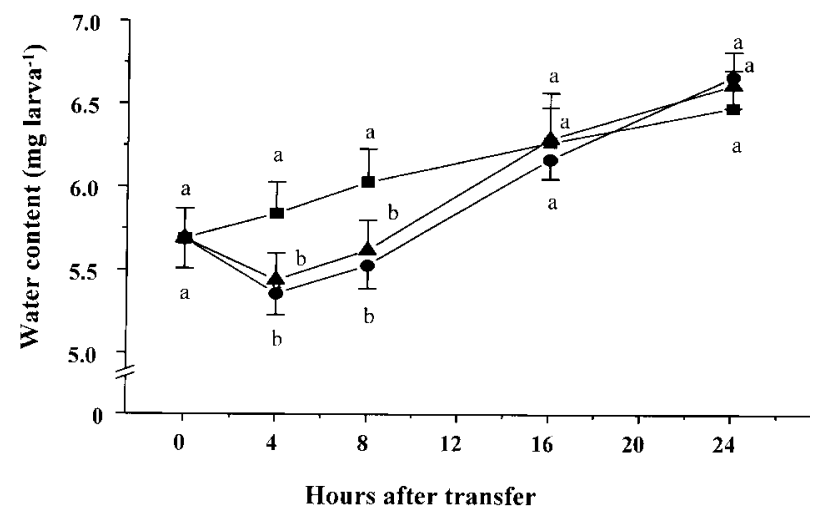

Figure 3. Changes in water content of cortisol-treated freshwater (FW) larvae (triangles) and sham FW larvae (circles) after transfer to $20 \mathrm{ppt}$ seawater (SW). Water contents of FW-adapted larvae (squares), which were kept in FW, are also shown. Treatment of cortisol refers to experiment 3 of "Material and Methods." One-way ANOVA (Tukey's pairwise comparisons) analysis was used to assess differences among different groups at the same time. Values represent $\bar{X} \pm \mathrm{SD}(n=10)$. Different letters indicate a significant difference $(P<0.05)$.

et al. 1998). These rapid actions of cortisol on hypoosmoregulation mechanisms in teleosts are of physiological significance and should not be discounted, as McCormick (1995) indicated.

One more notable finding from this study is that the effect of cortisol was inhibitory on drinking in tilapia adapted well to either SW or FW. One might argue that the decrease in the drinking rate could be due to a developmental delay and not really an inhibitory effect of cortisol since cortisol was demonstrated to retard development and growth in tilapia larvae (Mathiyalagan et al. 1996). It seems not to be the case because dry weight, body length, and yolk-sac diameter, which, reflecting some degree of larval development, showed no significant changes in both SW- and FW-adapted larvae after $10 \mathrm{mg} \mathrm{L}^{-1}$ cortisol immersion for $24 \mathrm{~h}$ (this study; Lin et al. 1999). Interestingly, exogenous cortisol inhibited water drinking in both SW and FW tilapia larvae, and this resulted in a decrease in the water content (and thus, the wet weight) of SW larvae but did not affect that in FW ones. This suggests that, in contrast to SW larvae, drinking is not a crucial mechanism of water balance for FW larvae.

The inhibitory effect of cortisol on drinking is interesting and a noteworthy phenomenon, although its acting mechanism and physiological significance is unclear. The renin-angiotensin system has been well documented to play a major role in control of drinking in fishes, and angiotensin II is the main biologically active component of the renin-angiotensin system (Olson 1992; Perrot et al. 1992; Tierney et al. 1995). In mammalian systems, cortisol is able to inhibit the secretion of arginine vasopressin by a feedback mechanism (Liu et al. 1995) and to regulate the expression of central angiotensin II (Ryan et al. 1997), implying that an interaction between cortisol and drinking activitylinked hormones is possible. In this finding, additional exogenous cortisol appeared to be redundant for the tilapia larvae that were well adapted to FW or SW and even inhibited normal drinking activity probably through a putative feedback pathway. Our other data ("Experiment 3") and those of Fuentes et al. (1996), i.e., cortisol promoting water drinking upon transfer from FW to SW, also support this possible interaction between cortisol and drinking activity-linked hormones. This interaction should be a subject for future studies.

\section{Acknowledgments}

Part of this study was supported by grants to P.-P.H. from the National Science Council, Taiwan, Republic of China (NSC88-2317-B-001-004). Appreciation is also expressed to Mr. C. I. Wang and Ms. Y. C. Tung for their assistance in tilapia rearing and collection.

\section{Literature Cited}

Alderdics D.F. 1988. Osmotic and ionic regulation in teleost eggs and larvae. Pp. 163-251 in W.S. Hoar and D.J. Randall, eds. Fish Physiology. Vol. 11A. Academic Press, New York.

Ayson F.G., T. Kaneko, S. Hasegawa, and T. Hirano. 1995. Cortisol stimulates the size and number of mitochondria-rich cells in the yolk-sac membrane of embryos and larvae of tilapia (Oreochromis mossambicus) in vitro and in vivo. J Exp Zool 272:419-425.

De Jesus E.G., T. Hirano, and Y. Inui. 1991. Changes of cortisol and thyroid hormone concentrations during early development and metamorphosis in the Japanese flounder, Paralivthys olivacesus. Gen Comp Endocrinol 82:369-376.

Eddy F.B. 1982. Osmotic and ionic regulation in captive fish with particular reference to salmonids. Comp Biochem Physiol 73B:125-142.

Forrest J.N., A.D. Cohen, D.A. Schon, and F.H. Epstein. 1973. $\mathrm{Na}^{+}$transport and $\mathrm{Na}-\mathrm{K}-\mathrm{ATP}$ ase in gills during adaptation to seawater: effects of cortisol. Am J Physiol 224:709-713.

Fuentes J., N.R. Bury, S. Carroll, and F.B. Eddy. 1996. Drinking in Atlantic salmon presmolts and juvenile rainbow trout in response to cortisol and sea water challenge. Aquaculture 141:129-137.

Guggino W.B. 1980a. Salt balance in embryo of Fundulus heteroclitus and F. bermudae in sea water. Am J Physiol 238: R42-R49.

. $1980 \mathrm{~b}$. Water balance in embryo of Fundulus heteroclitus and F. bermudae in sea water. Am J Physiol 238: R36-R41.

Hazon N. and R.J. Balment. 1998. Endocrinology. Pp. 441-464 
in D.H. Evans, ed. The Physiology of Fishes. CRC, Boca Raton, Fla.

Hwang P.-P. 1990. Salinity effects on development of chloride cells in the larvae of ayu Plecoglossus altivelis. Mar Biol 107: 1-7.

Hwang P.-P. and R. Hirano. 1985. Effects of environmental salinity on intercellular organization and junctional structure of chloride cells in early stages of teleost development. J Exp Zool 236:115-126.

Hwang P.-P., T.H. Lee, C.-F. Weng, M.J. Fang, and G.Y. Cho. 1999. Presence of Na-K-ATPase in mitochondria-rich cells in yolk-sac epithelium of larvae of the teleost, Oreochromis mossambicus. Physiol Biochem Zool 72:138-144.

Hwang P.-P., Y.N. Tsai, and Y.C. Tung. 1994. Calcium balance in embryos and larvae of the freshwater-adapted teleosts, Oreochromis mossambicus. Fish Physiol Biochem 13:325-333.

Hwang P.-P. and S.M. Wu. 1993. Role of cortisol in hypoosmoregulation in larvae of the tilapia, Oreochromic mossambicus. Gen Comp Endocrinol 92:318-324.

Hwang P.-P., S.M. Wu, J.H. Lin, and L.S. Wu. 1992. Cortisol content of eggs and larvae of teleosts. Gen Comp Endocrinol 86:189-196.

Lin G.R., C.F. Weng, J.I. Wang, and P.P. Hwang. 1999. Effects of cortisol on ion regulation in developing tilapia (Oreochromis mossambicus) larvae. Physiol Biochem Zool 72: 397-404.

Liu C., C.A. Wang, and Y.Z. Chen. 1995. Nongenomic effect of glucocorticoid on the release of arginine of vasopressin from hypothalamic slices in rats. Neuroendocrinology 62: 628-633.

Madsen S.S. 1990. Cortisol treatment improves the development of hypoosmoregulatory mechanisms in the euryhaline rainbow trout, Salmo gairdneri. Fish Physiol Biochem 8: $45-52$.

Mangor-Jensen A. and G.R. Adoff. 1987. Drinking activity of the newly hatched larvae of cod Gadus morhua L. Fish Physiol Biochem 3:99-103.

Marshall W.S., T.R. Emberley, T.D. Singer, S.E. Bryson, and S.D. McCormick. 1999. Time course of salinity adaptation in a strongly euryhaline estuarine teleost, Fundulus heteroclitus: a multivariable approach. J Exp Biol 202:1535-1544.

Mathiyalagan A., P.K. Reddy, and T.J. Lam. 1996. Effects of cortisol on growth and development in tilapia larvae, Oreochromic mossambicus. Fish Physiol Biochem 15:453-458.

McCormick S.D. 1990. Cortisol directly stimulates differentiation of chloride cells in the tilapia opercular membrane. Am J Physiol 259:R857-R863.
1995. Hormonal control of gill $\mathrm{Na}^{+}, \mathrm{K}^{+}$-ATPase and chloride cell function. Pp. 285-315 in C.M. Wood and T.J. Shuttleworth, eds. Fish Physiology. Vol. 14. Academic Press, New York.

Miyazaki H., T. Kaneko, S. Hasegawa, and T. Hirano. 1998. Developmental changes in drinking rate and water permeability during early life stages of euryhaline tilapia, Oreochromis mossambicus, rearing in fresh water and seawater. Fish Physiol Biochem 18:277-284.

Olson K.R. 1992. Blood and extracellular fluid volume regulation: role of the renin-angiotensin system, kallikerin-kinin system and atrial natriuretic peptides. Pp. 135-254 in W.S. Hoar and D.J. Randall, eds. Fish Physiology Vol. 12B. Academic Press, San Diego, Calif.

Perrot M.N., C.E. Grierson, N. Hazon, and R.J. Balment. 1992. Drinking behavior in sea water and fresh water teleosts, the role of the renin-angiotensin system. Fish Physiol Biochem 10:161-168.

Pickford G.E., P.K.T. Pang, E. Weinstein, and F.H. Epstein. 1970. The response of the hypophysectomized cyprinodont Fundulus heteroclitus, to replacement therapy with cortisol: effects on blood serum and sodium-potassium activated adenosine triphosphatase in the gills, kidney and intestinal mucosa. Gen Comp Endocrinol 14:522-534.

Richman N.H., III, R.S. Nishioka, G. Young, and H.A. Bern. 1987. Effects of cortisol and growth hormone replacement on osmoregulation in hypophysectomized coho salmon (Oncorhynchus kisutch). Gen Comp Endocrinol 67:194-201.

Ryan M.C., P.J. Shen, and A.L. Gundlach. 1997. Angiotensinogen and natriuretic peptide mRNAs in rat brain: localization and differential regulation by adrenal steroid in hypothalamus. Peptides 18:495-504.

Singer T.D., S.J. Tucker, W.S. Marshall, and C.F. Higgins. 1998. A divergent CFTR homologue: highly regulated salt transport in the euryhaline teleost F. heteroclitus. Am J Physiol 274: C715-C723.

Tierney M.L., G. Luke, G. Cramb, and N. Hazon. 1995. The role of the renin-angiotensin system in the control of blood pressure and drinking in the European eel, Anguilla anguilla. Gen Comp Endocrinol 100:39-48.

Tytler P. and J.H.S. Blaxter. 1988. Drinking in yolk sac stage larvae of the halibut, Hippoglossus hippoglossus. J Fish Biol 32:493-494.

Tytler P., M. Tatner, and C. Findlay. 1990. The ontogeny of drinking in the rainbow trout, Oncorhychus mykiss. J Fish Biol 36:867-875. 